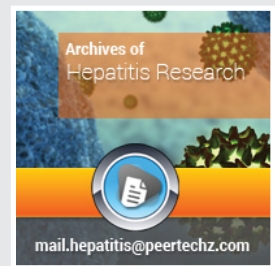

\title{
Clinical Group
}

\section{Archives of Hepatitis Research}

http://dx.doi.org/10.17352/ahr.000009

\section{Mohammad K Parvez*}

Department of Pharmacognosy, King Saud University College of Pharmacy, Riyadh 11451, Saudi Arabia

Dates: Received: 23 February, 2017; Accepted: 06 March, 2017; Published: 07 March, 2017

*Corresponding author: Mohammad K Parvez, Ph.D, Associate Professor, College of Pharmacy, King Saud University, P.O. Box 2457, Riyadh, 11451, Saudi Arabia, Tel: (+966)14675132; Fax: (+9661)14677245; E-mail:khalid_parvez@yahoo.com

https://www.peertechz.com

\section{Introduction}

Hepatitis E virus (HEV) is a globally important water and foodborne pathogen of acute and chronic hepatitis $E[1,2]$. HEV infection may be symptomatic or asymptomatic that has affected about one-third of world population with a case fatality rate of $1-2 \%$, including $20-30 \%$ of infected pregnant women [3-5]. Though inherently hepatotropic causing fulminant liver failure and cirrhosis, HEV has recently evolved with extra hepatic manifestations where biochemical/serological evidence of infection is often modest or absent [6-8].

HEV is a non-enveloped virus with a positive single-strand RNA genome $(\sim 7.2 \mathrm{~kb})$ with three partially overlapped open reading frames (ORF1, ORF2 and $\mathrm{ORF} 3$ ) [9]. Of the several recognized genotypes, HEV1 and $\mathrm{HEV} 2$ are known to infect humans only while $\mathrm{HEV}_{3}, \mathrm{HEV}_{4}$ and $\mathrm{HEV}_{7}$ are infectious to humans and other mammalian species, such as swine, boar and dear [10]. On the other hand, genotypes HEV5 and HEV6 have been detected in animals only, and their transmission to humans are not established [10]. Further, while HEV1 is endemic in Asia and Middle East, HEV2 is prevalent in African and South American countries. Contrarily, HEV3 and HEV4 are less pathogenic, and are mainly confined to Eastern Asian countries, Eastern and Western Europe, and North America [2]. Notably, in the Western countries, autochthonous HEV3 infection is attributed to sporadic cases of acute hepatitis, potentially linked to pork consumption [2]. In addition, HEV3 is also associated with chronic course of infection in solid organ transplant or blood transfusion patients where immunosuppressive drugs, like tacrolimus is considered as the main predictive factor for the disease severity [11].

\section{HEV diagnosis}

In acute hepatitis E, both anti-HEV IgM and IgG antibodies rise simultaneously in the narrow window of detectable HEV RNA. In general, seropositivity for anti-HEV IgG indicates previous HEV infection and occasionally, an ongoing infection. On the other hand, the positive anti-HEV IgM test indicates acute or recent infection. Several diagnostic assays for anti-HEV IgG and IgM are available; however, the use of anti-HEV IgM assays is still doubtful because of their unreliable specificity and sensitivity. While in Europe and Asia, many such anti-HEV assays are commonly used, none of these has been approved by the USA authorities. However, HEV testing is limited to few specialized centers and therefore, the hepatitis E diagnosis is often delayed in the USA [12]. Nonetheless, it still needs to be determined, which commercial assay has the greatest specificity and sensitivity. Recently, a new Wantai anti-HEV IgG assay kit (Wantai Biological Pharmacy Enterprise Co., Ltd, Beijing, China) has been preferred by many laboratories, worldwide for its consistent sensitivity and specificity compared to others [13]. Nonetheless, the universal gold standard for detecting ongoing HEV infection is the HEV-RNA tests in stool or blood samples by RT-PCR method. Recently, a WHO standard of HEV-RNA has been evaluated, which allows a comparison of qualitative and quantitative RT-PCR assays among different laboratories across the globe [14].

\section{Misdiagnosis}

The timely and proper diagnosis of hepatitis E is technically very challenging. In the absence of an approved algorithm, the consistency of serological tests and RNA quantification in terms of sensitivity and specificity are the limiting factors. Consequently, most of the 'first-generation' anti-HEV IgG assays-based studies had a very low seroprevalence $(<5 \%)$ in developed countries. It was mistaken that these positive individuals had either been exposed to HEV whilst visiting an endemic country or simply had non-specific cross-reactivity.

Prior to the knowledge of chronic HEV infection in immunosuppressed transplant recipients, it was frequently misdiagnosed as graft-versus-host disease, chronic rejection or drug-induced liver injury. Notably, acute hepatitis E is frequently misdiagnosed as drug-induced hepatotoxicity where the correct diagnosis is not secure without first excluding hepatitis E infection [15]. Moreover, the anti-HEV IgM falsepositivity was later shown because of past immunization against 
herpes viruses, like cytomegalovirus (CMV) and Epstein-Barr virus (EBV) [16]. Recently, a retrospective analysis of HEV serology has shown a high degree of cross-reactivity where approximately 33.3 and $24.2 \%$ of HEV IgM positive samples were also positive for EBV and CMV IgM, respectively [17]. Further, a case report has also revealed markers of past CMV and EBV infections in a hepatitis E patient with high fever, rash, arthralgia or AOSD-like symptoms [18]. Similarly, a chronic hepatitis E patient with systemic lupus erythematosus has been reported recently who was on immunosuppressant drugs therapy for 40 years [19]. While HEV diagnosis was based on persistent elevation of liver transaminases (ALT/ AST) and progressive liver fibrosis, the patient's immunologic profiles, like total lymphocyte count, $\mathrm{CD}_{4}+, \mathrm{CD} 8+$, and $\mathrm{CD} 3+$ $\mathrm{T}$ cell counts, including anti-HEV specific $\mathrm{T}-3$ cell response were ignored to conclude the etiology. Therefore, the diagnosis of HEV infection should be based on clinical presentations, elevated ALT/AST, serology, and confirmatory RNA test.

\section{Therapeutic interventions and drug failure}

Although one of the effective HEV vaccines [20,21], is approved in China, it is still not available in other countries, including the USA and Europe. Since HEV3 has been associated with the chronic infection, it is still unclear if this vaccine can prevent HEV3 in industrialized nations. Needlessly so far, there has been no established treatment for self-limiting acute hepatitis E. However, in recent times, pegylated interferon$\alpha-2 a$ (pegIFN-a-2a) and ribavirin (RBV) are shown effective drugs for treating acute liver failure and chronic patients. Though, RBV effectively inhibits the HEV replication and induce a sustained virological response (SVR) in chronic patients [22], drug-resistance or non-response associated viral mutations lead to therapeutic failure in a proportion of patients $[23,24]$.

Genetically, HEV also exists as a heterogeneous population within infected individuals. The drug (RBV) pressure in chronic patients may thus result in virus eradication as well as selection of replication competent quasi-species [25]. Recently, the correlation of RBV failure and disease severity with the detection of classical G1634R mutant, including new variants (K1383N, D1384G, K1398R, V1479I and Y1587Fl) in the RNA polymerase region of HEV ORF1 gene has been described [23]. Interestingly, the emergence of $\mathrm{K} 1383 \mathrm{~N}$ mutations and their association with an overall increase in viral heterogeneity in several patients, is shown reversible upon RBV cessation $[24,26]$.

\section{Conclusion}

Hepatitis E is a life-threatening infection in pregnant and immunosuppressed individuals where a proportion of patients fail to achieve SVR during RBV treatment. Nonetheless, the molecular mechanism of non-response or failure to RBV monotherapy in such cases still remains elusive. Several HEV false-positive results due to cross-reactivity have indicated the unreliability of the serological diagnosis of acute hepatitis E. Therefore, the diagnosis of HEV infection should be based on clinical presentation, biochemistry, serology and confirmatory viral RNA testing. Though within the last few years, a novel assay for the detection of HEV-antigen has been developed, its diagnostic fidelity still needs to be established prospectively in larger cohorts. In addition, a comprehensive clinical, virological and molecular data are needed to understand and control the viral paradigm shift of pathogenicity.

\section{References}

1. Aggarwal R, Naik S (2009) Epidemiology of hepatitis E: current status. J Gastroenterol Hepatol 24: 1484-1493. Link: https://goo.gl/yoHARO

2. Parvez MK (2013) Chronic hepatitis E infection: risks and controls Intervirology 56: 213-216. Link: https://goo.gl/TQ1Yfl

3. World Health Organization (2009) Viral hepatitis report by the Secretariat A62/22 Link: https://goo.gl/auXCQ1

4. Purcell RH, Emerson SU (2008) Hepatitis E: an emerging awareness of an old disease. J Hepatol 48: 494-503. Link: https://goo.gl/80Ygo4

5. Navaneethan U, Mohajer AIM, Shata MT (2008) Hepatitis E and pregnancy: understanding the pathogenesis. Liver Int 28: 1190-1199. Link: https://goo.gl/qQvze2

6. Parvez MK (2014) Hepatitis E virus-associated neuropathy: an emerging extrahepatic manifestation. Future Virol 9: 1-4. Link: https://goo.gl/zBswKH

7. Bazerbachi F, Haffar S, Garg SK, Lake JR (2016) Extra-hepatic manifestations associated with hepatitis $E$ virus infection: a comprehensive review of the literature. Gastroenterol Rep 4: 1-15. Link: https://goo.gl/KDh3ll

8. Zhou X, Huang F, Xu L, Lin Z, de Vrij FM, et al. (2017) Hepatitis E virus infects neurons and brains. J Infect Link: https://goo.gl/8cdOJT

9. Holla RP, Ahmad I, Ahmad Z, Jameel S (2013) Molecular virology of hepatitis E virus. Semin. Liver Dis 33: 3-14. Link: https://goo.gl/fcJ7sE

10. Dalton HR, Webb GW, Norton BC, Woolson KL (2016) Hepatitis E Virus: Time to Change the Textbooks. Dig Dis 34: 308-316. Link: https://goo.gl/OPHBWH

11. Haagsma EB, van den Berg AP, Porte RJ, Benne CA, Vennema H, et al. (2008) Chronic hepatitis $\mathrm{E}$ virus infection in liver transplant recipients. Liver Transp 14: 547-553. Link: https://goo.gl/0gyjuU

12. Yoo N, Bernstein J, Caldwell C, Dong C, Drobeniuc J, et al. (2012) Hepatitis $E$ virus infection in a liver transplant recipient: Delayed diagnosis due to variable performance of serologic assays. Transpl Infect Dis 15: 166-168. Link: https://goo.gl/b0Aoh9

13. Bendall R, Ellis V, ljaz S, Ali R, Dalton H (2010) A comparison of two commercially available anti-HEV IgG kits and a re-evaluation of anti-HEV IgG seroprevalence data in developed countries. J Med Virol 82: 799-805. Link: https://goo.gl/XSZcwa

14. Baylis SA, Blumel J, Mizusawa S, Matsubayashi K, Sakata H, et al. (2013) HEV Collaborative Study Group World Health Organization International Standard to harmonize assays for detection of hepatitis E virus RNA. Emerg Infec Dis19: 729-735. Link: https://goo.gl/i68jFp

15. Dalton HR, Fellows HJ, Stableforth W, Joseph M, Thurairajah P, et al. (2007) The role of HEV testing in drug-induced liver injury. Aliment Pharmacol Ther 26: 1429-1435. Link: https://goo.gl/rroc8K

16. Bento DP, Tavares R, Baptista LR, Miranda A, Ramos S, et al. (2010) AdultOnset Still's Disease and cytomegalovirus infection. ActaReumatol Port 35: 259-263. Link: https://goo.gl/BDzDtp

17. Hyams C, Mabayoje DA, Copping R, Maranao D, Patel M, et al. (2014) Serological cross reactivity to CMV and EBV causes problems in the diagnosis of acute hepatitis E virus infection. J Med Virol 86: 478-483. Link: https://goo.gl/ZFYkgM 
18. Al-Shukri I, Davidson E, Tan A, Smith DB, Wellington L, et al. (2013) Rash and arthralgia caused by hepatitis E. Lancet 382: 1856. Link: https://goo.gl/RsxJv1

19. Grewal P, Kamili S, Motamed D (2014) Chronic hepatitis E in an immunocompetent patient: A case report. Hepatology 59: 347-348. Link: https://goo.gl/CS5Vdc

20. Shrestha MP, Scott RM, Joshi DM, Mammen MP, Thapa GB, et al. (2007) Safety and efficacy of a recombinant hepatitis $\mathrm{E}$ vaccine. N Engl J Med 356: 895-903. Link: https://goo.gl/CVAkgw

21. Zhu FC, Zhang J, Zhang XF, Zhou C, Wang ZZ, et al. (2010) Efficacy and safety of a recombinant hepatitis $E$ vaccine in healthy adults: A large-scale, randomised, double-blind placebo-controlled, phase 3 trial. Lancet 376: 895902. Link: https://goo.gl/1stnpY

22. Kamar N, Rostaing L, Abravanel F, Garrouste C, Lhomme S, et al. (2010) Ribavirin therapy inhibits viral replication on patients with chronic hepatitis e virus infection. Gastroenterology 139: 1612-1618. Link: https://goo.gl/x5kyAZ

23. Debing Y, Gisa A, Dallmeier K, Pischke S, Bremer B, et al. (2014) A Mutation in the hepatitis $E$ virus RNA polymerase promotes its replication and associates with ribavirin treatment failure in organ transplant recipients. Gastroenterology 147: 1008-1011. Link: https://goo.gl/hIQuKA

24. Todt D, Gisa A, Radonic A, Nitsche A, Behrendt $P$, et al. (2016) In vivo evidence for ribavirin-induced mutagenesis of the hepatitis $E$ virus genome. Gut 65 : 1733-1743. Link: https://goo.gl/sKJne8

25. Todt D, Walter S, Brown RJ, Steinmann E (2016) Mutagenic Effects of Ribavirin on Hepatitis E Virus-Viral Extinction versus Selection of FitnessEnhancing Mutations. Viruses 8: 283. Link: https://goo.gl/YeDXpg

26. Debing Y, Ramiere C, Dallmeier K, Piorkowski G, Trabaud MA, et al. (2016) Hepatitis $E$ virus mutations associated with ribavirin treatment failure result in altered viral fitness and ribavirin sensitivity. J Hepatol 65: 499-508. Link: https://goo.gl/NhbLyp 